\title{
ANALISIS REKOMENDASI PENGGUNAAN PROVIDER TELEKOMUNIKASI SELULER BERDASARKAN PENGUKURAN BANDWIDTH PADA MASA PANDEMI
}

\author{
Hadryan Eddy ${ }^{1}$, Kusrini ${ }^{2}$, Asro Nasiri ${ }^{3}$ \\ Magister Teknik Informatika, Universitas AMIKOM YOGYAKARTA ${ }^{1,2,3}$ \\ Email : hadryan.1186@students.amikom.ac.id ${ }^{1}$, kusrini@amikom.ac.id², \\ asro@amikom.ac.id ${ }^{3}$
}

\begin{abstract}
ABSTRAK
Penelitian ini bertujuan untuk memberikan rekomendasi penggunaan penyelenggara telekomunikasi seluler untuk digunakan dalam pembelajaran online pada saat pandemi. Penelitian ini merupakan penelitian eksperimental dimana peneliti mengumpulkan data secara manual dengan membandingkan penggunaan bandwidth download dan upload dari masingmasing provider telekomunikasi selular yang ada di Kabupaten Mamuju. Penelitian ini dilakukan pada saat pandemi COVID-19 berdampak pada proses belajar mengajar yang harus dilakukan secara online maupun jarak jauh yang tentunya membutuhkan konektivitas internet yang baik. Penelitian ini menggunakan metode kuantitatif dan analisis komparatif dengan mengumpulkan data bandwidth download dan bandwidth upload menggunakan NetLimiter dari tiga penyelenggara telekomunikasi seluler yaitu Telkomsel, XL, dan Indosat di Kabupaten Mamuju. Kemudian data tersebut diolah dengan menghitung bandwidth. Hasil analisis data yang diperoleh adalah Telkomsel dengan bandwidth download 0,0136 MBps, upload 0,0147 MBps, bandwidth download XL 0,0116 MBps, upload 0,0129 MBps, bandwidth download Indosat 0,0066 MBps, upload 0,0162 MBps. Hasil penelitian ini menunjukkan bahwa di antara ketiga provider tersebut, Telkomsel lebih unggul dalam penggunaan bandwidth download dengan ukuran 0,0136 MBps. Sebaliknya untuk penggunaan bandwidth upload disarankan menggunakan Indosat dengan ukuran 0.0162 MBps. Meski demikian, secara keseluruhan analisis provider, Telkomsel merupakan provider yang direkomendasikan untuk menggunakan aplikasi konferensi video karena adanya kesenjangan antara penggunaan bandwidth download dengan ukuran 0,0136 MBps dan upload dengan ukuran 0,0147 MBps yang tidak terlalu signifikan dan lebih stabil dibandingkan lainnya. Saran untuk penelitian selanjutnya adalah dilakukan pengukuran ulang dengan melihat faktor sebaran atau jumlah BTS di daerah tersebut.
\end{abstract}

Kata Kunci: Bandwidth, COVID-19, Pembelajaran Daring

\section{ABSTRACT}

This study aims to provide recommendations for the use of cellular telecommunications providers for use in online learning during a pandemic. This study used an experimental study in which the researcher collected data manually by comparing the download and upload bandwidth usage of each available cellular telecommunications provider in the Mamuju district. This research was conducted during the COVID-19 pandemic to impact the teaching 
and learning process, which must do online or remotely, which certainly requires good internet connectivity. This research uses quantitative methods and comparative analysis by collecting data download bandwidth and upload bandwidth using NetLimiter from three cellular telecommunications providers, namely Telkomsel, XL, and Indosat in Mamuju district. Then the data is processed by calculating the bandwidth. The results of data analysis obtained are Telkomsel with a download bandwidth of 0.0136 MBps, upload 0.0147 MBps, XL download bandwidth 0.0116 MBps, upload 0.0129 MBps, Indosat download bandwidth $0.0066 \mathrm{MBps}$, upload $0.0162 \mathrm{MBps}$. The results of this study show that among the three providers, Telkomsel is superior in the use of download bandwidth with a size of 0.0136 MBps. In contrast, for upload bandwidth usage, it is recommended to use Indosat with a size of $0.0162 \mathrm{MBps}$. Still, an overall analysis of the provider, Telkomsel is a recommended provider for using video conferencing applications due to gaps Between the download bandwidth usage with a size of $0.0136 \mathrm{MBps}$ and upload with a size of $0.0147 \mathrm{MBps}$ is not too significant and more stable than other providers. Suggestions for further research are re-measurement by looking at the distribution factor or the number of BTS in the area.

Keywords: Bandwidth, COVID-19, Online Learning

\section{PENDAHULUAN}

Pada saat ini dunia digital telah berkembang pesat sehingga hal ini telah mengubah trend dalam kehidupan bermasyarakat, salah satu trend saat ini yang paling berkembang pesat adalah komunikasi seluler sehingga hal tersebut membuat masyarakat harus memilih hal penunjang dalam menentukan kenyamanan saat melakukan pencarian informasi dalam dunia digital adapun penunjang tersebut adalah penentuan provider telekomunikasi yang akan digunakan. Berdasarkan data yang di dapatkan dari nperf.com terdapat tiga provider utama yang tersedia di wilayah kabupaten Mamuju, yaitu Telkomsel, XL, dan Indosat.

Dalam menentukan penggunaan provider telekomunikasi seluler terdapat beberapa indikasi dalam menentukan provider, dalam hal ini penggunaan bandwidth yang merupakan salah satu parameter dalam quality of service (QoS) difokuskan untuk menentukan penggunaan provider untuk melakukan akses pembelajaran jarak jauh dikarenakan penggunaan bandwidth memiliki detail dalam penggunaan kapasitas transmisi data baik total penggunaan maupun penggunaan transmisi secara langsung dengan menggunakan satuan bit per detik.

COVID-19 adalah sebuah virus menular yang disebabkan oleh Severe Acute Respiratory Syndrome Coronavirus 2 (SARS-CoV-2). SARS-CoV-2 atau biasa disebut dengan COVID-19 merupakan virus jenis baru yang belum pernah diidentifikasi sebelumnya pada manusia. Ada dua kemungkinan penyebab gejala yang dimunculkan oleh COVID-19 seperti Middle East Respiratory Syndrome (MERS) dan Severe Acute Respiratory Syndrome (SARS). Tanda dan gejala ringan yang ditimbulkan oleh penyakit COVID-19 antara lain gejala gangguan pernapasan akut seperti demam, batuk dan sesak napas adapun untuk gejala berat yang ditimbulkan yaitu pneumonia, sindrom pernapasan akut, 
gagal ginjal, dan bahkan kematian (Kesehatan, 2020).

Pada masa COVID-19 saat ini untuk mencegah perkembangan virus yang sangat cepat pemerintah melakukan pembatasan tatap muka sehingga sistem belajar mengajar pun juga memiliki batasan. Pembelajaran yang dilaksanakan untuk mencegah terjadinya tatap muka salah satunya yaitu melakukan pembelajaran secara Daring/jarak jauh yang memanfaatkan jaringan internet sebagai acuan untuk melakukan pembelajaran (Dewi, 2020).

GSM merupakan singkatan dari Global System for Mobile Communications. GSM adalah standar telepon seluler di seluruh dunia, dengan penyebaran di lebih dari 210 negara dengan 860 operator jaringan. yang menyediakan mobilitas terminal, dengan mobilitas pribadi yang disediakan melalui penyisipan modul identitas pelanggan atau Subscriber Identity Module (SIM) ke dalam jaringan GSM (Varshavsky et al., 2007). Provider merupakan penyedia layanan. Provider ini mengacu kepada provider penyedia layanan telekomunikasi seperti Telkomsel, XL dan Indosat. Telkomsel adalah operator telekomunikasi seluler terbesar di Indonesia dengan 171,1 juta pengguna per 2019 lalu, kemudian disusul oleh Indosat dengan 59,3 juta pengguna dan yang XL dengan 56,7 juta pelanggan.

Zoom merupakan sebuah perangkat lunak (software) yang digunakan di era digital sekarang apalagi dengan kondisi pandemi yang tidak memungkinkan untuk melakukan meeting secara tatap muka langsung (offline). Zoom membantu bisnis dan organisasi menyatukan tim mereka dalam lingkungan tanpa kendala untuk menyelesaikan lebih banyak pekerjaan.
Platform cloud kami yang mudah dan andal untuk video, suara, berbagi konten, dan obrolan berjalan di seluruh perangkat seluler, desktop, telepon, dan sistem ruangan. Zoom diperdagangkan secara publik di Nasdaq (ZM) dan berkantor pusat di San Jose, California (Zoom, 2020)

QoS (Quality of Service) merupakan sebuah metode atau cara untuk menentukan dan mengukur kemampuan suatu jaringan untuk memberikan layanan terbaik pada lalu lintas jaringan tertentu melalui teknologi yang berbeda. QoS memiliki sebuah parameter sebagai acuan untuk menentukan baik atau buruknya suatu jaringan, dalam hal ini penggunaan parameter bandwidth dalam QoS dilakukan untuk mengukur penggunaan bandwidth dalam melakukan pembelajaran secara daring (Charisma et al., 2019) .

Penelitian ini dilakukan untuk memberikan rekomendasi penggunaan provider telekomunikasi seluler berdasarkan penggunaan bandwidth.

\section{LANDASAN TEORI}

Pada salah satu penelitian terdahulu yang dilakukan oleh Karisma, A dkk menjelaskan tentang penelitian yang telah dilakukan di kota padat penduduk Soreang menggunakan provider Telkomsel untuk mengetahui kualitas jaringan internet dengan menggunakan tools wireshark dengan parameter QoS sebagai acuan penelitian mendapatkan hasil bahwa performa jaringan terbaik di wilayah Soreang yaitu pada malam hari berdasarkan standarisasi dari TIPHON tanpa adanya masalah pada parameter QoS (Charisma et al., 2019). 
Pada penelitian lain yang dilakukan oleh YaoJun dkk menjelaskan bahwa wireless wide area network (WWAN) yang muncul tidak menjamin kualitas dari bandwidth yang digunakan pada wilayah tertentu dan waktu tertentu sehingga bandwidth yang didapatkan sangat berbeda dari penyedia jaringan yang sama di lokasi yang berbeda. Penelitian ini menunjukan penggunaan bandwidth spesifik wilayah tertentu di masa lampau dapat meningkatkan QoS secara signifikan pada aplikasi streaming multimedia dalam mobilitas penggunaan bandwidth. (Yao, Kanhere dan Hassan, 2012).

Pada penelitian yang dilakukan oleh Goyal dkk yang bertujuan untuk menentukan $Q o S$ dalam pemilihan jaringan di alam dengan melakukan perbandingan QoS pada alat WLAN, WiMaX dan UMTS yang mana lebih efektif. Agregasi beberapa kriteria untuk perhitungan keseluruhan peringkat jaringan diperoleh dengan menggunakan metode Analytic Hierarchy Process (AHP) untuk menyelesaikan masalah inkonsistensi. User equipment (UE) seluler 4G dapat menjelajah dengan bebas di berbagai nirkabel sistem dengan melakukan penyerahan horizontal dan vertikal. Sedemikian lingkungan, pemilihan jaringan dari yang tersedia sistem nirkabel pada dasarnya sulit. Untuk memilih yang terbaik jaringan dari sistem nirkabel dan untuk mencapai $Q o S, A H P$ diimplementasikan. Menurut skema yang diusulkan, bobot ditugaskan ke kriteria yang berbeda dan memperoleh peringkat akhir jaringan alternatif. Hasil menunjukkan bahwa keterlambatan tersebut adalah kriteria penting selama proses serah terima dan WLAN jaringan optimal antara WiMAX dan UMTS.
Karenanya, itu memberikan $Q o S$ yang lebih baik ke jaringan karena mengurangi keseluruhan keterlambatan dalam jaringan (Goyal dan Kaushal, 2016).

Dari beberapa penelitian sebelumnya terdapat beberapa perbedaan yang dengan penelitian yang telah dilakukan seperti objek penelitian penggunaan provider telekomunikasi yang sebelumnya hanya menggunakan Telkomsel. Kini, bertambah dua provider lain yaitu, XL dan Indosat. Kemudian, lokasi penelitian juga berada di Kabupaten Mamuju. Objek penelitian fokus terhadap penggunaan provider telekomunikasi seluler dengan parameter pengukuran bandwidth untuk mendukung baik belajar dan mengajar secara daring dengan menggunakan medium aplikasi Zoom.

Pada penelitian ini fokus penulis yaitu komparasi penggunaan bandwidth pada aplikasi Zoom sebagai acuan untuk dasar perbandingan pemilihan provider telekomunikasi seluler terbaik antara Telkomsel, XL, dan Indosat dalam melakukan analisis. Alasan penggunaan aplikasi video conference dalam hal ini yaitu Zoom dikarenakan aplikasi tersebut berdasarkan pada survei yang dilakukan oleh Perhimpunan untuk Pendidikan dan Guru Indonesia (P2GI) yang diramkum pada web katadata.co.id pada 3 Desember 2020 dari hasil survei didapatkan bahwa penggunaan aplikasi untuk pembelajaran online yang berbasis media sosial dalam hal ini yaitu WhatsApp, Facebook, Line, dan Instagram sebanyak $70 \%$ sedangkan untuk focus pada penggunaan aplikasi pembelajaran daring yang berbasis video conference menunjukan sebanyak $42 \%$ responden menggunakan aplikasi Zoom, $31 \%$ responden menggunakan aplikasi 
Google Meet, dan kurang dari 10\% penggunaan aplikasi lainnya yaitu Cisco Webex, Microsoft Teams, U Meet Me, Rumah Belajar, Quipper Schoil, Edmodo, dan Ruang Guru.

\section{METODE PENELITIAN}

Penelitian ini dilakukan dengan mengumpulkan data di tiga tempat serta waktu yang berbeda di Kab. Mamuju. Data yang digunakan pada penelitian ini merupakan data dari parameter bandwidth yang dikhususkan dalam penggunaan data dalam melakukan pembelajaran secara daring dan menggunakan data dari analisis tiap provider yang dikumpulkan sebanyak 324 data dalam satuan MBps (MegaByte persecond) yang berbeda dari masing wilayah, waktu dan provider untuk memaksimalkan pengujian provider telekomunikasi seluler sehingga menghasilkan rekomendasi penggunaan provider telekomunikasi seluler pada masa pandemi. Penelitian ini menggunakan jenis penelitian yang bersifat experimental, dimana pada penelitian ini ada serangkaian tindakan yang dilakukan, dimulai dari pencarian variabel yang digunakan untuk mengukur salah satu parameter QoS yaitu bandwidth.

\subsection{Quality of Service (QoS)}

Quality of Service (QoS) merupakan suatu teknologi yang memungkinkan seorang administrator jaringan untuk mencegah dan menangani permasalahan dari efek kongesti pada aliran lalu lintas paket data dari berbagai sumber jaringan secara optimal dibandingkan dengan melakukan peningkatan secara fisik pada perangkat jaringan (Iskandar dan Hidayat, 2015). Dari definisi diatas dapat disimpulkan QoS (Quality of Service) adalah kemampuan suatu jaringan untuk menyediakan layanan yang baik. Oleh karenanya buruk atau baiknya kualitas dan kemampuan suatu jaringan dapat kita ukur melalui unjuk kerja jaringan tersebut. Pada penelitian kali ini peneliti menggunakan parameter bandwidth yang merupakan salah satu parameter yang ada dalam QoS untuk melakukan analisis dimana parameter tersebut merupakan kebutuhan utama dalam melakukan pembelajaran secara daring.

\subsection{Bandwidth}

Bandwidth adalah jumlah dari kapasitas suatu perangkat jaringan, dalam hal ini yaitu kabel ethernet yang dapat dilewati oleh paket data dalam jumlah tertentu. bandwidth pada dasarnya representasi dari kapasitas koneksi, dimana semakin tinggi kapasitas maka umumnya menghasilkan kinerja yang lebih baik akan tetapi ada faktor lain yang mempengaruhi seperti latency dimana waktu yang tertunda pada sebuah perangkat untuk meminta akses ke jaringan dan masa perangkat itu memberikan izin untuk melakukan transmisi (Mutiara, Giva Andriana, ST. MT., Surya Kencana P dan Idham Iskandar, 2012). Satuan perhitungan yang digunakan untuk menghitung bandwidth pada persamaan (1).

Bandwidth $=\frac{\text { Jumlah konsumsi paket data }}{\text { waktu(s) }}$

\subsection{NetLimiter}

NetLimiter adalah aplikasi pemantauan dan kontrol lalu lintas internet alat untuk platform Microsoft Windows. NetLimiter menggabungkan berbagai fitur seperti monitor jaringan, pemblokir koneksi, editor aturan, dan penjadwal yang menandai ini 
alat sebagai aplikasi pemantauan jaringan yang baik.

Sebagian besar fitur-fiturnya terbatas namun untuk versi lengkap jaringan pembatas, versi gratisnya hanya menyertakan monitor jaringan (Locktime Software s.r.o, 2017)

Penggunaan NetLimiter dalam hal ini digunakan untuk melakukan pengumpulan data terhadap parameter bandwidth yang merupakan salah satu parameter QoS.

\section{HASIL DAN PEMBAHASAN}

Berikut ini adalah penjelasan terhadap beberapa teori dan penelitian terkait dengan konsep dan tahapan proses analisis pada penelitian ini.

\subsection{Pengumpulan Data}

Berikut ini tahapan yang dilakukan dalam melakukan pengumpulan data dengan menggunakan standarisasi TIPHON dalam hal ini pengumpulan data Tabel 1 Data minggu pertama di lokasi difokuskan pada bandwidth dengan menggunakan aplikasi NetLimiter, serta menjalankan meeting Zoom dengan jumlah partisipan 4 pengguna dengan durasi waktu 10 menit sebagai acuan untuk melakukan pengumpulan data dari tiap-tiap provider telekomunikasi seluler seperti Telkomsel, XL dan Indosat. Pengumpulan data diambil di 3 (tiga) lokasi dengan rentang waktu berbeda, pada minggu pertama di Telkom, minggu kedua di Karema Utara dan minggu ketiga di Kasiwa.

Penggunaan NetLimiter dalam penelitian ini bertujuan untuk melakukan pengumpulan data terhadap parameter bandwidth.

Berdasarkan pengukuran penggunaan bandwidth yang dilakukan dengan menggunakan aplikasi NetLimiter yang memiliki satuan MB (Megabyte) maka didapatkan pada tabel 1, tabel 2, dan tabel 3 .

\begin{tabular}{|c|c|c|c|c|c|c|}
\hline \multirow{2}{*}{ Provider } & \multirow{2}{*}{ Waktu } & \multicolumn{5}{|c|}{ Hari } \\
\cline { 3 - 7 } & & \multicolumn{2}{|c|}{ Senin } & $\cdots$ & \multicolumn{2}{c|}{ Sabtu } \\
\cline { 3 - 7 } & & Download & Upload & $\ldots$ & Download & Upload \\
\hline Telkomsel & $09.00-09.10$ & 19.41 & 18.67 & $\cdots$ & 6.85 & 11.22 \\
\hline XL & $09.20-09.30$ & 9.71 & 18.94 & $\cdots$ & 2.08 & 5.99 \\
\hline Indosat & $09.40-09.50$ & 5.95 & 15.53 & $\cdots$ & 5.51 & 10.4 \\
\hline$\ldots$ & $\ldots$ & $\cdots$ & $\cdots$ & $\cdots$ & $\cdots$ & $\cdots$ \\
\hline Telkomsel & $13.00-13.10$ & 10.78 & 9.41 & $\cdots$ & 5.07 & 19.38 \\
\hline XL & $13.20-13.30$ & 12.46 & 17.88 & $\cdots$ & 6.48 & 11.44 \\
\hline Indosat & $13.40-13.50$ & 8.54 & 8.45 & $\cdots$ & 3.88 & 6.97 \\
\hline
\end{tabular}

Dari hasil pengumpulan data yang dilakukan dengan menggunakan aplikasi Netlimiter didapatkan nilai pada tabel 1 terdapat dua parameter bandwidth yang dikumpulkan selama enam hari yaitu bandwidth download dan bandwidth upload pada lokasi pertama yang merupakan wilayah Binanga dengan detail waktu dan provider yang digunakan. 
Tabel 2 Data minggu kedua di lokasi Karema Utara

\begin{tabular}{|c|c|c|c|c|c|c|}
\hline \multirow{2}{*}{ Provider } & \multirow{2}{*}{ Waktu } & \multicolumn{5}{|c|}{ Hari } \\
\cline { 3 - 7 } & & \multicolumn{2}{|c|}{ Senin } & $\cdots$ & \multicolumn{2}{c|}{ Sabtu } \\
\cline { 3 - 7 } & & Download & Upload & $\cdots$ & Download & Upload \\
\hline Telkomsel & $09.00-09.10$ & 7.24 & 13.15 & $\cdots$ & 10.34 & 6.21 \\
\hline XL & $09.20-09.30$ & 2.09 & 7.58 & $\cdots$ & 15.97 & 11.33 \\
\hline Indosat & $09.40-09.50$ & 3.54 & 9.01 & $\cdots$ & 2.92 & 8.43 \\
\hline$\ldots$ & $\ldots$ & $\cdots$ & $\cdots$ & $\cdots$ & $\cdots$ & $\cdots$ \\
\hline Telkomsel & $13.00-13.10$ & 4.84 & 10.02 & $\cdots$ & 2.22 & 7.97 \\
\hline XL & $13.20-13.30$ & 4.72 & 9.17 & $\cdots$ & 5.21 & 3.68 \\
\hline Indosat & $13.40-13.50$ & 3.18 & 6.08 & $\cdots$ & 2.88 & 5.84 \\
\hline
\end{tabular}

Dari hasil pengumpulan data yang dilakukan dengan menggunakan aplikasi Netlimiter didapatkan nilai pada tabel 2 terdapat dua parameter bandwidth yang dikumpulkan selama enam hari yaitu bandwidth download dan bandwidth upload pada lokasi pertama yang merupakan wilayah Karema Utara dengan detail waktu dan provider yang digunakan.

Tabel 3 Data minggu ketiga di lokasi Kasiwa

\begin{tabular}{|c|c|c|c|c|c|c|}
\hline \multirow{2}{*}{ Provider } & \multirow{2}{*}{ Waktu } & \multicolumn{4}{|c|}{ Hari } \\
\cline { 3 - 7 } & & \multicolumn{2}{|c|}{ Senin } & $\cdots$ & \multicolumn{2}{c|}{ Sabtu } \\
\cline { 3 - 7 } & & Download & Upload & $\cdots$ & Download & Upload \\
\hline Telkomsel & $09.00-09.10$ & 4.96 & 10.69 & $\ldots$ & 8.75 & 6.37 \\
\hline XL & $09.20-09.30$ & 5.27 & 5.71 & $\cdots$ & 4.39 & 9.84 \\
\hline Indosat & $09.40-09.50$ & 3.89 & 7.38 & $\cdots$ & 2.92 & 8.43 \\
\hline$\ldots$ & $\ldots$ & $\ldots$ & $\cdots$ & $\cdots$ & $\ldots$ & $\cdots$ \\
\hline Telkomsel & $13.00-13.10$ & 9.06 & 8.8 & $\cdots$ & 4.93 & 4.61 \\
\hline XL & $13.20-13.30$ & 4.58 & 4.04 & $\cdots$ & 11.22 & 12.57 \\
\hline Indosat & $13.40-13.50$ & 2.36 & 5.62 & $\cdots$ & 3.94 & 7.35 \\
\hline
\end{tabular}

Dari hasil pengumpulan data yang dilakukan dengan menggunakan aplikasi Netlimiter didapatkan nilai pada tabel 3 terdapat dua parameter bandwidth yang dikumpulkan selama enam hari yaitu bandwidth download dan bandwidth upload pada lokasi pertama yang merupakan 
wilayah Kasiwa dengan detail waktu dan provider yang digunakan.

\subsection{Analisis Data}

Setelah dilakukan pengumpulan data selanjutnya dilakukan tahap analisis data yang dilakukan dengan menghitung bandwidth pada persamaan (1).

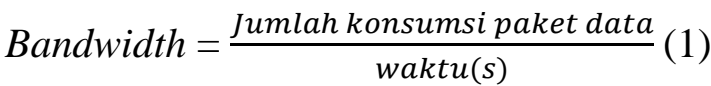

Dari hasil perhitungan tersebut maka didapatkan data rata-rata penggunaan bandwidth dengan satuan MBps (Megabyte per second)

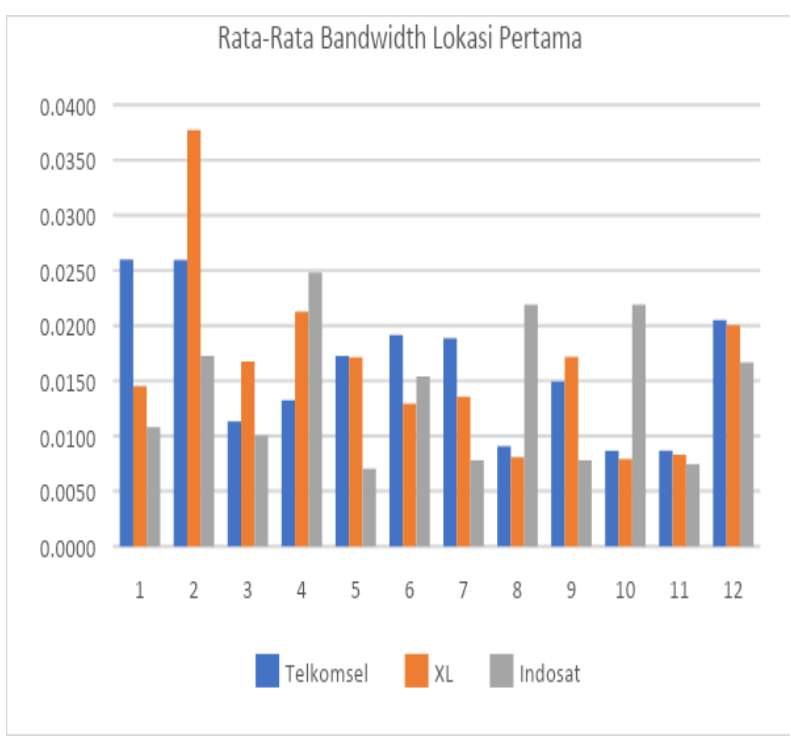

\section{Gambar 1 Data rata-rata bandwidth lokasi Telkom}

Setelah dilakukan analisis didapatkan data pada gambar 1 menunjukan bahwa didapatkan download tertinggi dicapai oleh Telkomsel dengan besaran 0.0260 MBps sedangkan untuk upload tertinggi yaitu XL dengan besaran 0.0377 MBps dalam analisis yang dilakukan pada minggu pertama.

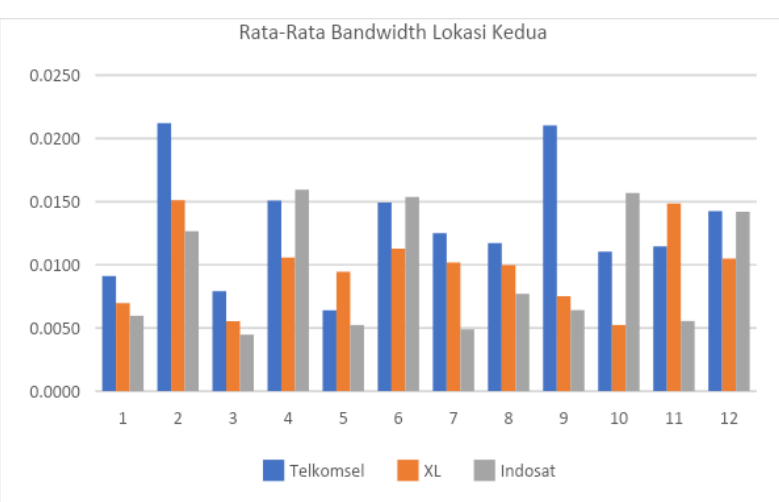

Gambar 2 Data rata-rata bandwidth lokasi Karema Utara

Setelah dilakukan analisis didapatkan data pada gambar 2 menunjukan bahwa didapatkan download tertinggi dicapai oleh Telkomsel dengan besaran 0.0210 MBps sedangkan untuk upload tertinggi yaitu Telkomsel dengan besaran 0.0212 MBps dalam analisis yang dilakukan pada minggu kedua.

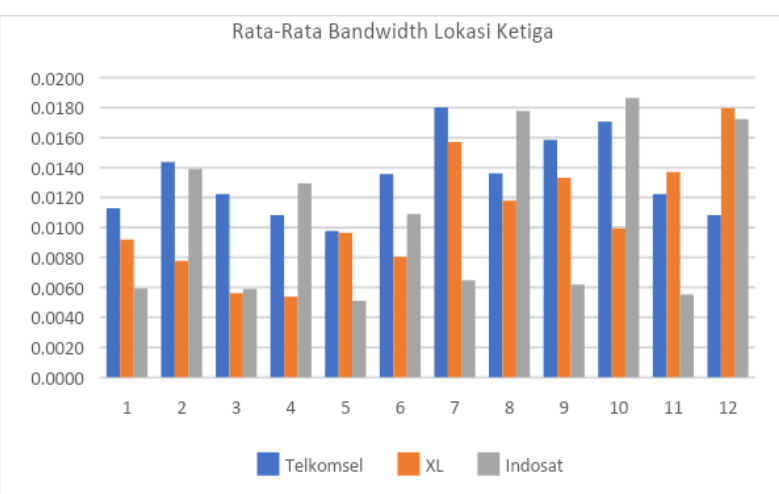

\section{Gambar 3 Data rata-rata bandwidth} lokasi Kasiwa

Setelah dilakukan analisis didapatkan data pada gambar 3 menunjukan bahwa didapatkan download tertinggi dicapai oleh Telkomsel dengan besaran 0.0180 MBps sedangkan untuk upload tertinggi yaitu Indosat dengan besaran 0.0186 MBps dalam analisis yang dilakukan pada minggu ketiga. 


\subsection{Hasil}

Setelah dilakukan analisis dengan menggunakan perhitungan bandwidth selanjutnya dilakukan perhitungan rata-rata keseluruhan untuk mendapatkan rekomendasi penggunaan provider di tiap wilayah yang ditunjukan pada Gambar dibawah ini:

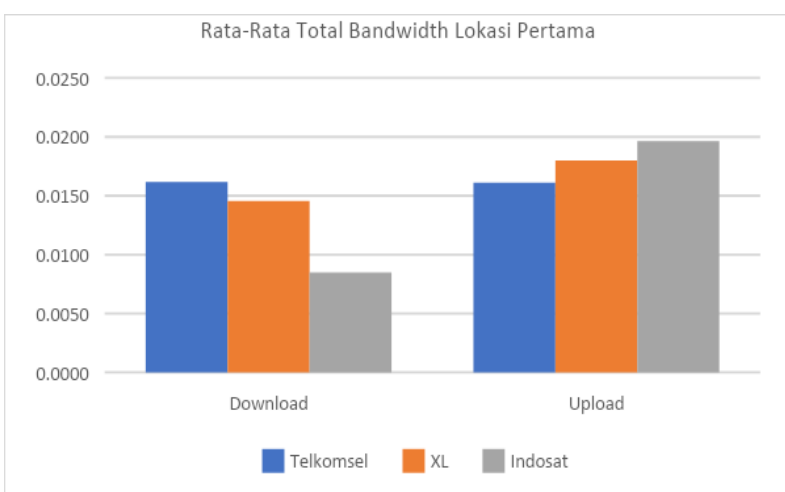

\section{Gambar 4 Rata-Rata Total Bandwidth Lokasi Pertama}

Pada gambar 4 menunjukan bahwa analisis yang dilakukan secara menyeluruh pada lokasi pertama provider Telkomsel unggul pada bandwidth download dengan besaran 0.0162 MBps sedangkan provider Indosat unggul pada bandwidth upload dengan besaran 0.0197 MBps.

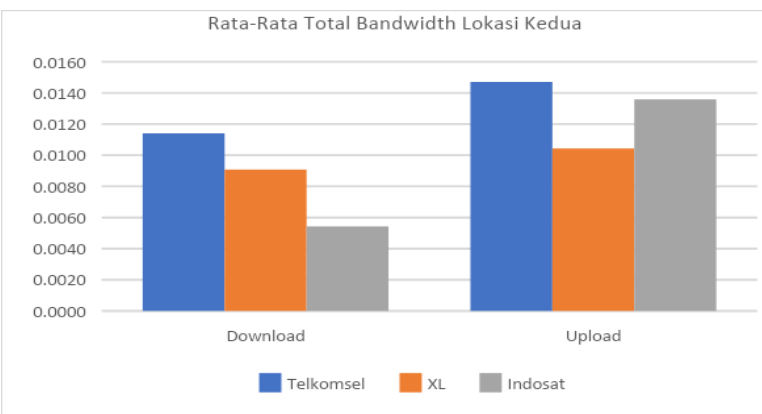

\section{Gambar 5 Rata-Rata Total Bandwidth Lokasi Kedua}

Pada Gambar 5 menunjukan bahwa analisis yang dilakukan secara menyeluruh pada lokasi kedua provider Telkomsel unggul pada bandwidth download dan upload dengan besaran 0.0114 MBps dan 0.0147 MBps.

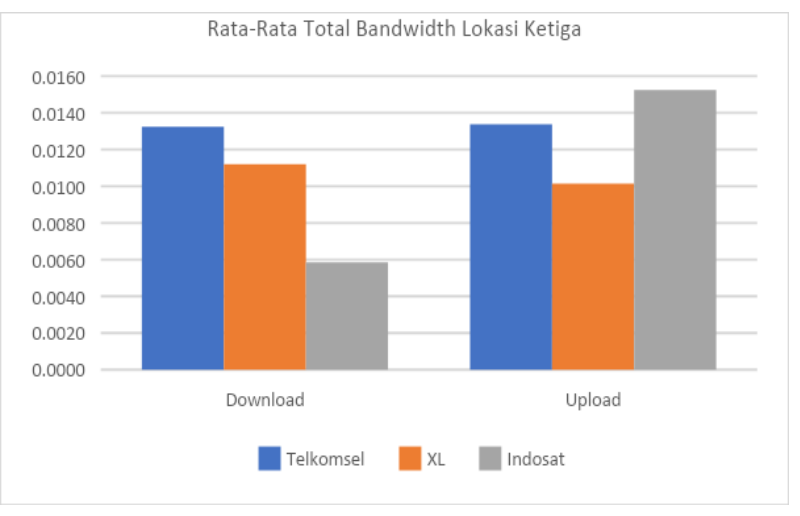

\section{Gambar 6 Rata-Rata Total Bandwidth Lokasi Ketiga}

Pada Gambar 6 menunjukan bahwa analisis yang dilakukan secara menyeluruh pada lokasi pertama provider Telkomsel unggul pada bandwidth download dengan besaran 0.0132 MBps sedangkan provider Indosat unggul pada bandwidth upload dengan besaran 0.0152 MBps.

Data yang telah dianalisis pada ketiga tempat tersebut kemudian dilakukan perhitungan rata-rata pada bandwidth download dan upload setiap provider telekomunikasi seluler untuk menentukan provider mana yang unggul pada tiap bandwidth download dan upload untuk menentukan rekomendasi penggunaan provider secara menyeluruh di kabupaten Mamuju.

Tabel 4 Rekomendasi penggunaan provider menyeluruh

\begin{tabular}{|c|c|c|}
\hline \multirow{2}{*}{ Provider } & \multicolumn{2}{|c|}{ Bandwidth } \\
\cline { 2 - 3 } & Download & Upload \\
\hline Telkomsel & 0.0136 & 0.0147 \\
\hline XL & 0.0116 & 0.0129 \\
\hline Indosat & 0.0066 & 0.0162 \\
\hline
\end{tabular}


Pada tabel 4 menunjukkan bahwa penggunaan bandwidth download direkomendasikan menggunakan provider Telkomsel dengan besaran $0.0136 \mathrm{MBps}$ di wilayah kabupaten Mamuju sedangkan untuk penggunaan bandwidth upload direkomendasikan menggunakan provider Indosat dengan besaran $0.0162 \mathrm{MBps}$. Kemudian untuk penggunaan secara menyeluruh direkomendasikan menggunakan provider Telkomsel dikarenakan kesenjangan antara penggunaan bandwidth download dengan besaran 0.0136 MBps dan upload dengan besaran 0.0147 MBps tidak terlalu signifikan dan lebih stabil dibandingkan provider lainnya.

\section{SIMPULAN DAN SARAN}

Telah dilakukan pengumpulan data kemudian dianalisis dari tiap lokasi yang telah ditentukan pada tiga provider telekomunikasi seluler, Telkomsel, XL dan Indosat pada wilayah kabupaten Mamuju memiliki Hasil analisis data yang didapatkan adalah Telkomsel dengan bandwidth download $0.0136 \mathrm{MBps}$, upload 0.0147 MBps, Xl bandwidth download 0.0116 MBps, upload 0.0129 MBps, Indosat bandwidth download 0.0066 MBps, upload 0.0162 MBps. Kemudian dapat ditarik kesimpulan bahwasanya diantara ketiga provider tersebut, Telkomsel unggul pada penggunaan bandwidth download dengan besaran $0.0136 \mathrm{MBps}$ sedangkan untuk penggunaan bandwidth upload direkomendasikan menggunakan provider Indosat dengan besaran $0.0162 \mathrm{MBps}$ tetapi analisis secauploadra menyeluruh, Telkomsel menjadi rekomendasi provider untuk penggunaan aplikasi video conference dikarenakan kesenjangan antara penggunaan bandwidth download dengan besaran 0.0136 MBps dan upload dengan besaran 0.0147 MBps tidak terlalu signifikan dan lebih stabil dibandingkan provider lainnya.

Penelitian ini dapat dilanjutkan dengan mencari tahu penyebaran BTS masingmasing provider Telkomsel, XL dan Indosat di wilayah kabupaten Mamuju dan melakukan komparasi ulang terhadap tiga provider tersebut di wilayah kabupaten Mamuju dan mencari tahu kenapa tidak terjadi perbedaan signifikan kualitas antara provider tersebut.

\section{DAFTAR PUSTAKA}

Charisma, A. et al. (2019). Analysis Quality of Service (QoS) on 4G Telkomsel Networks In Soreang. 2019 IEEE 13th International Conference on Telecommunication Systems, Services, and Applications (TSSA), hal. 145-148.

Dewi, W. A. F. (2020). Dampak COVID19 terhadap Implementasi Pembelajaran Daring di Sekolah Dasar. Edukatif: Jurnal Ilmu Pendidikan, 2(1), hal. 55-61. doi: 10.31004/edukatif.v2i1.89.

Goyal, T. dan Kaushal, S. (2016). Optimized network selection during handover using analytic hierarchy process in $4 \mathrm{G}$ network. Proceedings - 2016 International Conference on Advances in Computing, Communication and Automation, ICACCA 2016, hal. 25. doi: 10.1109/ICACCA.2016.7578873.

Iskandar, I. dan Hidayat, A. (2015). Analisa Quality of Service (QoS) Jaringan Internet Kampus (Studi Kasus: UIN Suska Riau). Jurnal CoreIT, 1(2), 
hal. 67-76.

Kesehatan, K. (2020). Pedoman Pencegahan dan Pengendalian Coronavirus disease (Covid-19). Kementerian Kesehatan, 5, hal. 178. Tersedia pada: https://covid19.go.id/storage/app/m edia/Protokol/REV-

05_Pedoman_P2_COVID19_13_Juli_2020.pdf.

Locktime Software s.r.o (2017). Netlimiter. Tersedia pada: https://www.netlimiter.com/produc ts/n14.

Mutiara, Giva Andriana, ST. MT., Surya Kencana P, M. dan Idham Iskandar, S. (2012). Implementasi Algoritma Per Connection Queue (PCQ) Dalam Algoritma Hierarchical Token Bucket (HTB) Untuk Pembagian Bandwidth Pada Warnet Khelambiqunet. Politeknik Telkom Bandung 9 (5), 2.

Varshavsky, A. et al. (2007). GSM indoor localization. Pervasive and Mobile Computing, 3(6), hal. 698-720. doi: 10.1016/j.pmcj.2007.07.004.

Yao, J., Kanhere, S. S. dan Hassan, M. (2012). Improving QoS in highspeed mobility using bandwidth maps. IEEE Transactions on Mobile Computing, 11(4), hal. 603617. doi: 10.1109/TMC.2011.97. 